\title{
PENGARUH TERAPI KOGNITIF TERHADAP TINGKAT KECEMASAN PADA PASIEN GAGAL GINJAL KRONIK YANG MENJALANI HEMODIALISA
}

\author{
Dian Eka Nurjanah, Hermansyah, Nur Elly \\ Politeknik Kesehatan Kementerian Kesehatan Bengkulu, Jurusan Keperawatan, \\ Jalan Indragiri Nomor 03 Padang Harapan Kota Bengkulu \\ deeaneka_ohohhoho@yahoo.co.id
}

\begin{abstract}
Individuals with long- term hemodialysis often feel anxious about the pain condition that cannot be foreseen and disruption in their lives. The results of the survey conducted in hospitals Hemodialysis Space M. Yunus Bengkulu on 10 samples obtained, 6 of them experienced moderate anxiety and 4 patients experienced mild anxiety. The purpose of the study was to determine the effect of cognitive therapy on anxiety of patients with chronic renal failure undergoing hemodialysis therapy. This research is Pre Experimental design one group pretestposttest. The population in this study were all patients with chronic renal failure undergoing hemodialysis therapy Hemodialysis Hospital in Space M. Yunus Bengkulu, which is 184 people . Samples taken by accidental sampling as many as 30 patients with chronic renal failure undergoing hemodialysis therapy. Data collected by direct interview to the patient. Data analysis was performed using univariate and bivariate Paired t-test at $\alpha 5 \%$. The results showed that the average anxiety patient with chronic renal failure undergoing hemodialysis therapy prior to cognitive therapy was 9.33 , while the average anxiety after cognitive therapy was 6.6. There was an average difference of anxiety before and after cognitive therapy, and there was a significant decrease between the average anxiety after cognitive therapy cognitive therapy than before in patients with chronic renal failure undergoing hemodialysis therapy Hemodialysis Hospital in Space M. Yunus Bengkulu ( $\mathrm{p}$ value $=0.000$ ).
\end{abstract}

Keywords : Anxiety, Cognitive Therapy

\begin{abstract}
Abstrak : Individu dengan haemodialisis jangka panjang sering merasa cemas akan kondisi sakitnya yang tidak dapat diramalkan dan gangguan dalam kehidupannya. Hasil survey yang dilakukan di Ruang Hemodialisa RSUD M. Yunus Bengkulu pada 10 orang sampel didapatkan, 6 diantaranya mengalami kecemasan sedang dan 4 orang pasien mengalami kecemasan ringan. Tujuan penelitian adalah untuk mengetahui pengaruh terapi kognitif terhadap kecemasan pasien gagal ginjal kronik yang menjalani terapi hemodialisa. Jenis penelitian ini adalah Pra Eksperimental dengan desain one group pretest-posttest. Populasi dalam penelitian ini adalah seluruh pasien gagal ginjal kronik yang menjalani terapi hemodialisa di Ruang Hemodialisa RSUD M. Yunus Bengkulu, yaitu 184 orang. Sampel diambil secara accidental sampling sebanyak 30 orang pasien gagal ginjal kronik yang menjalani terapi hemodialisa. Pengumpulan data dilakukan dengan wawancara langsung kepada pasien. Analisis data dilakukan secara univariat dan bivariat dengan uji Paired T-test pada $\alpha$ 5\%. Hasil penelitian menunjukkan bahwa rata-rata kecemasan pasien gagal ginjal kronik yang menjalani terapi hemodialisa sebelum dilakukan terapi kognitif adalah 9,33, sedangkan rata-rata kecemasan setelah dilakukan terapi kognitif adalah 6,6. Ada perbedaan rata-rata kecemasan sebelum dan setelah dilakukan terapi kognitif, dan ada penurunan yang signifikan antara rata-rata kecemasan setelah dilakukan terapi kognitif dibandingkan sebelum dilakukan terapi kognitif pada pasien gagal ginjal kronik yang menjalani terapi hemodialisa di Ruang Hemodialisa RSUD M. Yunus Bengkulu ( $p$ value $=0,000)$.
\end{abstract}

Keywords : Kecemasan, Terapi Kognitif

Gagal ginjal kronis atau penyakit renal tahap akhir (End Stage Renal Disease) merupakan gangguan fungsi renal yang progresif dan irreversibel dimana kemampuan tubuh gagal untuk mempertahankan metabolisme dan keseimbangan cairan dan elektrolit yang menyebabkan uremia (retensi urea dan sampah nitrogen lain dalam darah). Dialisis atau 
transplantasi ginjal dibutuhkan untuk kelangsungan hidup penderita gagal ginjal kronis (Brunner \& Suddarth, 2001).

Hemodialisis merupakan suatu proses yang digunakan pada pasien dalam keadaan sakit akut dan memerlukan terapi dialisis jangka pendek atau pasien dengan penyakit ginjal stadium terminal (ESRD; end-stage renal disease) yang membutuhkan terapi jangka panjang atau terapi permanen. Sebagian besar pasien terapi rawat jalan membutuhkan 10-15 jam haemodialisa setiap minggunya yang dapat terbagi dalam dua atau tiga kali, tergantung pada nilai kreatinin dimana setiap kali berlangsung antara 3-4 jam. Kegiatan ini akan terus menerus berlangsung selama hidupnya, atau sampai mendapat ginjal baru melalui pencangkokan yang berhasil (Brunner \& Suddarth, 2001).

Keadaan ketergantungan pada dialisa seumur hidup mengakibatkan terjadinya perubahan dalam kehidupan penderita gagal ginjal kronik. Individu dengan haemodialisa jangka panjang sering merasa cemas akan kondisi sakitnya yang tidak dapat diramalkan dan gangguan dalam kehidupannya, mereka biasanya mengalami masalah finansial, kesulitan dalam mempertahankan pekerjaan, dorongan seksual yang menghilang, serta impotensi, depresi akibat sakit yang kronis dan kecemasan terhadap kematian (Brunner and Suddarth, 2001).

Kecemasan merupakan perasaan tidak nyaman dan ketakutan yang tidak menyenangkan (Davison \& Kring, 2004). Menurut Barraclough (1999), kecemasan seringkali diikuti oleh gejala mental (psikologis) dan gejala fisik (somatis). Pada umumnya, gejala mental mudah dikenali seperti khawatir, mudah merasa terganggu (irritability), gelisah (restlessness), insomnia, atau mimpi buruk. Sedangkan gejala fisik tampak pada pernafasan menjadi cepat, aktivitas berlebih pada sistem saraf otonom dan tegangan otot, jantung berdebar-debar, berkeringat, sakit kepala, terdapat gumpalan pada tenggorokan yang menyebabkan kesulitan dalam menelan, pusing, sakit perut dan diare.

Salah satu faktor yang membuat pasien yang menjalankan haemodialisa merasa ce- mas atau khawatir adalah pengetahuan tentang penyakit dan perawatan yang kurang. Biasanya pasien tidak memahami sepenuhnya dampak dialisa dan kebutuhan untuk mempelajarinya yang baru disadarinya setelah dipulangkan dari rumah sakit (Brunner \& Suddarth, 2001). Tingkat kecemasan klien hemodialisis dipengaruhi oleh beberapa faktor fisiologis dan biologis, baik dari dalam maupun dari luar pasien, penerimaan terhadap pelaksanaan hemodialisis, sosial ekonomi, usia pasien, serta kondisi pasien (Wayan, 2012).

Hasil penelitian yang dilakukan Alisa (2012) terhadap tingkat kecemasan pasien hemodialisa RSUD Dr. M Yunus Bengkulu menunjukkan $66,1 \%$ pasien tingkat kecemasannya sedang dan 33,9\% tingkat kecemasannya ringan.

Menanggulangi atau menurunkan kecemasan pasien adalah salah satu tugas perawat. Salah satu caranya yaitu dengan komunikasi. Fenomena yang ada sekarang bahwa komunikasi yang dilakukan perawat sebagai orang yang terdekat dan paling lama berada di dekat pasien cenderung mengarah pada tugas perawat dari pada mengenali kecemasan dan persepsi pasien tentang tindakan yang menyebabkan kecemasan (Ellis et all, 1999).

Salah satu terapi yang sesuai untuk kecemasan yaitu terapi kognitif (Eldido, 2008). Terapi kognitif merupakan terapi untuk mengubah cara berpikir tentang sesuatu atau memodifikasi keyakinan negatif yang berlebihan (Holmes, 2005). Terapi kognitif bertujuan membantu mengenali cacat-cacat logis dalam pikiran mereka untuk melihat situasi secara rasional.

Terapi kognitif atau Cognitive Behavioral Therapy merupakan aplikasi dari berbagai variasi teori belajar dalam kehidupan (Yosep, 2009). Tujuannya adalah untuk menolong seseorang keluar dari kesulitannya dalam berbagai bidang kehidupan dan pengalaman. Terapi kognitif behavioral berfokus pada masalah dan berorientasi pada tujuan, diarahkan pada masalah-masalah yang berkembang pada situasi sekarang dan saat ini (deals with here and now issues), 
yang memandang individu sebagai pengambil keputusan penting tentang tujuan atau masalah yang akan dipecahkan dalam proses terapi. Terapi kognitif behavior diharapkan berperan sebagai mekanisme proteksi agar kecemasan dan depresi tidak mengancam, karena pasien belajar mengatasi faktor-faktor yang menyebabkan munculnya gangguan (Nasir \& Muhith, 2011).

Hasil observasi awal yang dilakukan peneliti di ruang Hemodialisa RSUD M. Yunus pada September 2012 pada 10 orang pasien 6 diantaranya mengalami kecemasan sedang dan 4 orang pasien mengalami kecemasan ringan.

Tujuan penelitian ini adalah diketahuinya pengaruh pemberian terapi kognitif terhadap tingkat kecemasan pasien gagal ginjal kronik yang menjalani terapi hemodialisa di ruang hemodialisa RSUD Dr. M. Yunus Bengkulu tahun 2013.

\section{BAHAN DAN CARA KERJA}

Jenis penelitian yang digunakan adalah Pre eksperimental dengan rancangan one group pre and post test. Populasi penelitian ini adalah seluruh pasien gagal ginjal kronik yang menjalani terapi hemodialisa di ruang Hemodialisa RSUD Dr. M. Yunus Bengkulu tahun 2012 yang berjumlah 184 orang. Jumlah sampel dalam penelitian ini adalah 30 orang (Kasjono, 2009), tekhnik pengambilan sampel dengan accidental sampling. Penelitian dilakukan di ruang Hemodialisa RSUD Dr. M. Yunus Bengkulu dari bulan Oktober 2012 hingga bulan Mei 2013. Analisis yang digunakan adalah analisis univariat dan bivariat dengan uji statistisk paired t-test. Instrumen penelitian yang digunakan peneliti yaitu Depression Anxiety Stress Scale 21 (DASS 21) Lovibond \& Lovibond (1995). DASS 21 merupakan hasil revisi dari DASS 42 yang digunakan untuk mengukur depresi, kecemasan, dan stress. Dalam penelitian ini penulis hanya melakukan analisa terhadap itemitem yang merujuk pada kecemasan, yaitu nomor 2,4,7,9,15,19,20. Data kecemasan diambil langsung dari responden dengan cara wawancara langsung sebelum responden mendapatkan terapi hemodialisa dan data post perlakuan diambil dengan cara yang sama pada saat responden akan mendapatkan terapi hemodialisa selanjutnya.

\section{HASIL}

Karakteristik responden pada penelitian ini adalah untuk melihat distribusi responden berdasarkan tingkat pendidikan dan usia responden.

Tabel 1. Distribusi Responden Berdasarkan Tingkat Pendidikan dan Umur di Ruang hemodialisa RSUD M. Yunus Bengkulu

\begin{tabular}{lcc}
\hline \multicolumn{1}{c}{ Variabel } & $\begin{array}{c}\text { Frekuensi } \\
(\mathbf{n}=\mathbf{3 0})\end{array}$ & $\begin{array}{c}\text { Persen } \\
(\mathbf{1 0 0} \%)\end{array}$ \\
\hline Tingkat pendidikan & & \\
SD & 2 & 6,7 \\
SMP & 5 & 16,7 \\
SMA & 15 & 50 \\
PT & 8 & 26,7 \\
Umur & & \\
$16-25$ & 1 & 3,3 \\
$26-35$ & 3 & 10,0 \\
$36-45$ & 5 & 16,7 \\
$46-55$ & 17 & 56,7 \\
$56-65$ & 3 & 10,0 \\
$>65$ & 1 & 3,3 \\
\hline
\end{tabular}

Tabel 1 menunjukkan bahwa sebagian (50\%) responden berpendidikan SMA dan umur responden lebih dari sebagian $(56,7 \%)$ berusia 46-55 tahun.

\section{Analisa Univariat}

Analisis univariat pada penelitian ini adalah untuk melihat mean, median, standar deviasi, nilai minimum-maksimum, $95 \%$ CI of mean tingkat kecemasan pasien gagal ginjal kronik yang menjalani terapi hemodialisa sebelum dan setelah dilakukan pemberian terapi kognitif.

Hasil analisis pada tabel 2 didapatkan bahwa lebih dari sebagian $(63,3 \%)$ responden mengalami kecemasan ringan sebelum dilakukan intervensi. Sedangkan hasil analisis setelah intervensi didapatkan bahwa lebih dari sebagian $(63,3 \%)$ responden tidak mengalami kecemasan setelah dilakukan intervensi. 
Tabel 2. Distribusi Tingkat Kecemasan Responden Sebelum dan Setelah Dilakukan Intervensi

\begin{tabular}{lcc}
\hline Tingkat Kecemasan & Frekuensi & Persen $(\%)$ \\
\hline Sebelum Intervensi & & \\
Tidak cemas & 0 & 0 \\
Cemas ringan & 19 & 63,3 \\
Cemas sedang & 10 & 33,3 \\
Cemas berat & 1 & 3,3 \\
Cemas sangat berat & 0 & 0 \\
Sebelum Intervensi & & \\
Tidak cemas & 19 & 63,3 \\
Cemas ringan & 11 & 36,7 \\
Cemas sedang & 0 & 0 \\
Cemas berat & 0 & 0 \\
Cemas sangat berat & 0 & 0 \\
Jumlah & 30 & 100 \\
\hline
\end{tabular}

Hasil analisis pada tabel 3 didapatkan rata-rata kecemasan pasien gagal ginjal kronik yang menjalani terapi hemodialisa sebelum mendapatkan terapi kognitif adalah 9,33 dengan standar deviasi 1,605. Nilai kecemasan pasien gagal ginjal kronik yang menjalani terapi hemodialisa sebelum mendapatkan terapi kognitif terkecil adalah 8 dan nilai terbesar 15. Dari hasil estimasi interval dapat disimpulkan bahwa 95\% diyakini rata-rata kecemasan pasien gagal ginjal kronik yang menjalani terapi hemodialisa sebelum mendapatkan terapi kognitif adalah diantara 8,73 sampai dengan 9,93.

Tabel 3. Distribusi Rata-rata Kecemasan Pasien Gagal Ginjal Kronik yang Menjalani Terapi Hemodialisa Sebelum dan Setelah Dilakukan Terapi Kognitif

\begin{tabular}{lccccc}
\hline Variabel & N & $\begin{array}{c}\text { Mean } \\
\text { Median }\end{array}$ & SD & $\begin{array}{c}\text { Min- } \\
\text { Maks }\end{array}$ & $\begin{array}{c}\text { 95\% CI } \\
\text { of mean }\end{array}$ \\
\hline $\begin{array}{l}\text { Kecemasan } \\
\text { sebelum } \\
\text { terapi kognitif }\end{array}$ & 30 & 9,33 & 1,605 & $8-15$ & $8,73-9,93$ \\
$\begin{array}{l}\text { Kecemasan } \\
\text { setelah terapi }\end{array}$ & 30 & 6,67 & 1,470 & $4-9$ & $6,12-7,22$ \\
kognitif & 7,00 & & & \\
\hline
\end{tabular}

Sedangkan hasil analisis rata-rata kecemasan pasien gagal ginjal kronik yang menjalani terapi hemodialisa setelah mendapatkan terapi kognitif adalah 6,67 dengan standar deviasi 1,470. Nilai kecemasan pasien gagal ginjal kronik yang menjalani terapi hemodialisa setelah mendapatkan terapi kognitif terkecil adalah 4 dan nilai terbesar 9. Dari hasil estimasi interval dapat disimpulkan bahwa 95\% diyakini rata-rata kecemasan pasien gagal ginjal kronik yang menjalani terapi hemodialisa setelah mendapatkan terapi kognitif adalah diantara 6,12 sampai dengan 7,22 .

\section{Analisa Bivariat}

Analisis bivariat ini dilakukan untuk mengetahui adanya penurunan kecemasan sebelum dan seseudah dilakukan treatment (terapi kognitif) yaitu dengan menguji paired T-test pada $\alpha 5 \%$ one tail (satu sisi).

Tabel 4. Distribusi Perbedaan Rata-rata Kecemasan Responden Sebelum dan Setelah Dilakukan Terapi Kognitif

\begin{tabular}{|c|c|c|c|c|c|c|}
\hline $\begin{array}{c}\text { Tingkat } \\
\text { Kecemasan }\end{array}$ & $\mathbf{N}$ & Mean & SD & $\mathbf{S E}$ & $\begin{array}{c}T \\
(\mathbf{d f})\end{array}$ & $\rho$ \\
\hline $\begin{array}{l}\text { Sebelum } \\
\text { Intervensi }\end{array}$ & 30 & 9,33 & 1,605 & 0,293 & \multirow{2}{*}{$\begin{array}{c}8,868 \\
(29)\end{array}$} & \multirow{2}{*}{0,000} \\
\hline $\begin{array}{l}\text { Setelah } \\
\text { Intervensi }\end{array}$ & 30 & 6,67 & 1,470 & 0,268 & & \\
\hline
\end{tabular}

Hasil uji statistik menunjukkan bahwa nilai $\rho=0,000<5 \%$ (one tail), artinya ada penurunan rata-rata kecemasan pasien gagal ginjal kronik yang menjalani terapi hemodialisa setelah intervensi terapi kognitif dibandingkan dengan sebelum dilakukan intervensi terapi kognitif. Dapat disimpulkan bahwa ada pengaruh terapi kognitif terhadap penurunan kecemasan pasien gagal ginjal kronik yang menjalani terapi hemodialisa di Ruang Hemodialisa di RSUD Dr. M. Yunus Bengkulu tahun 2013.

\section{PEMBAHASAN}

\section{Gambaran Kecemasan Pasien Gagal Ginjal Kronik y ang Menjalani Terapi Hemodialisa Sebelum dan Setelah Dilakukan Terapi Kog- nitif}

Hasil analisis didapatkan nilai rata-rata kecemasan pasien gagal ginjal kronik yang menjalani terapi hemodialisa sebelum dilakukan terapi kognitif adalah 9,33 (95\% CI = $8,73-9,93)$. Sedangkan hasil analisis didapatkan nilai rata-rata kecemasan pasien gagal ginjal kronik yang menjalani terapi hemodialisa setelah dilakukan terapi kognitif ada- 
lah 6,67 (95\% CI = 6,12-7,22). Hal ini menunjukkan bahwa pasien yang menjalani hemodialisa mengalami kecemasan. Keadaan ini sesuai dengan penelitian yang dilakukan oleh Alisa (2012), bahwa dari 56 responden sebagian besar atau $37(66,1 \%)$ responden memiliki tingkat kecemasan pada kategori sedang, dan sisanya 19 (33,9\%) responden memiliki tingkat kecemasan kategori ringan.

Kecemasan merupakan suatu kondisi yang muncul bila ada ancaman ketidakberdayaan atau kurang pengendalian, perasaan kehilangan fungsi-fungsi dan harga diri, kegagalan pertahanan, perasaan terisolasi (Anonim, 2009).

Hasil observasi selama penelitian, responden yang mengalami kecemasan ditandai dengan mulut terasa kering, merasa gangguan saat bernapas (sesak, napas cepat), gemetar, merasa takut dan kawatir, dan jantung berdebar-debar. Pasien juga cenderung lebih cepat kesal dan marah. Ketika diajak bicara, mereka seperti tergesa-gesa dan enggan dalam menjawab pertanyaan yang diajukan. Akan tetapi mereka masih dapat diajak untuk kerjasama dan mematuhi prosedur pengobatan.

Hal ini diperkuat oleh Arliza (2006), bahwa respon klien dengan penyakit kronik dan keadaan terminal lain yaitu kehilangan kesehatan, kehilangan kemandirian, kehilangan situasi, kehilangan rasa nyaman, kehilangan fungsi fisik, kehilangan fungsi mental (cemas, depresi), dan kehilangan konsep diri.

Menurut Suliswati (2005), secara fisiologis tubuh manusia selalu merespon situasi yang penuh dengan kecemasan. Ada dua respon yang penting, yaitu melawan atau lari (fight of flight respons). Respon fight or flight respons adalah sederetan perubahanperubahan yang terjadi dalam tubuh untuk menyiapkan diri guna merespons situasi yang berbahaya dan menegangkan. Perubahan-perubahan ini termasuk meningkatnya denyut jantung, ketegangan otot, perubahan pola napas dan laju metabolik. Keadaan ini berlangsung sementara saat menghadapi situasi darurat seperti waktu menjalani hemo- dialisa. Setelah stressor berlalu, mekanisme kerja tubuh akan kembali normal.

\section{Perbedaan Rata-Rata Kecemasan Pasien Ga- gal Ginjal Kronik yang Menjalani Terapi Hemodialisa Sebelum dan Setelah Dilakukan Terapi Kognitif}

Hasil penelitian menunjukkan rata-rata perbedaan kecemasan pasien gagal ginjal kronik yang menjalani terapi hemodialisa sebelum dan setelah dilakukan terapi kognitif adalah 2,667. Hasil penelitian juga menunjukkan ada penurunan rata-rata kecemasan pasien gagal ginjal kronik yang menjalani terapi hemodialisa setelah mendapatkan terapi kognitif dibandingkan sebelum mendapatkan terapi kognitif $(\rho=0,000)$. Keadaan ini menunjukkan bahwa hampir semua responden yang mengalami penurunan kecemasan setelah dilakukan tindakan terapi kognitif.

Terapi kognitif adalah stategi memodifikasi keyakinan dan sikap yang mempengaruhi perasaan dan perilaku klien. Proses yang diterapkan adalah membantu mempertimbangkan stressor dan kemudian dilanjutkan dengan mengidentifi kasi pola berpikir dan keyakinan yang tudak akurat tentang streesor tersebut. Gangguan ansietas terjadi akibat klien mengalami pola dan keyakinan berpikir yang tidak akurat. Untuk itu, salah satu cara memodifikasinya adalah dengan mengubah pola pikir dan keyakinan tersebut. Fokus asuhan ini adalah membantu klien untuk merevaluasi ide, nilai yag diyakini, harapan-harapan, dan kemudian dilanjutkan dengan menyusun perubahan kognitif (Majnun, 2009).

Teori kognitif menjelaskan bahwa perilaku dipengaruhi oleh persepsi atau interpretasi di lingkungannya selama suatu proses berlangsung. Munculnya perilaku yang abnormal dilatarbelakangi oleh adanya misinterpretation dan misperception. Dengan adanya terapi, maka pemahaman yang salah dapat dikoreksi sehingga memunculkan perilaku yang sesuai dengan lingkungannya. Menurut Saputra (2008), emosi ataupun rasa cemas tersebut disebabkan oleh adanya dialog internal dalam pikiran individu yang menga- 
lami kecemasan atau perasaan cemas. Dialog internal pada pasien gagal ginjal kronik yang menjalani terapi hemodialisa biasanya diawali melalui persepsi yang salah terhadap penyakit dan terapi hemodialisa, sehingga menghasilkan interpretasi secara subjektif tentang keadaan tersebut.

Penelitian ini sesuai dengan penelitian Wahyuningsih, et all (2010) di Rumah Sakit Margono Soekarjo Purwokerto, yang menggambarkan skor kecemasan pada kelompok intervensi sebelum dilakukan terapi kognitif yaitu 54,81 dengan skor min-max 31-78 dan setelah terapi kognitif 38,56 dengan skor min-max 28-49. Sedangkan pada kelompok kontrol skor kecemasan sebelum terapi kognitif 51,25 dengan skor min-max 34-62 dan setelah 50,3 dengan skor min-max 36-62. Hal ini menunjukkan bahwa terapi kognitif mempunyai pengaruh signifikan terhadap variabel tingkat kecemasan pasien gagal ginjal kronik yang menjalani hemodialisa.

\section{KESIMPULAN}

Berdasarkan hasil penelitian dan pembahasan pengaruh terapi kognitif terhadap penurunan kecemasan pasien gagal ginjal kronik yang menjalani terapi hemodialisa, maka dapat disimpulkan bahwa ada penurunan rata-rata kecemasan pasien gagal ginjal kronik yang menjalani terapi hemodialisa

\section{DAFTAR RUJUKAN}

Alisa. 2012. Hubungan Mekanisme Koping dan Lama Menjalani Hemodialisa dengan Tingkat Kecemasan Klien Gagal Ginjal Kronis di Ruang Hemodialisa RSUD Dr. M. Yunus Bengkulu Tahun 2012. KTI. Tidak Dipublikasikan

Anonim. 2009. Kemampuan Koping Terhadap Tingkat Kecemasan Pada Klien Gagal Ginjal Kronik Yang Menjalani Hemodialisa. Diakses tanggal $23 \quad$ September 2013. http://grahacedikia.wordpress.com/2009/12/19

Arliza.2006. Dukungan Sosial pada Pasien Gagal Ginjal Terminal yang Melakukan Terapi Hemodialisa. Diakses tanggal 25 September 2012. www.library.usu.ac.id

Barraclough. 1999. Cancer and Emotion A Practical Guide to Psycho-Oncology Third Edition. setelah dilakukan terapi kognitif dibandingkan sebelum dilakukan terapi kognitif di ruang hemodialisa RSUD M. Yunus Bengkulu tahun $2013(\rho=0,000)$.

Berdasarkan hasil penelitian dan pembahasan, peneliti ingin memberikan saran kepada beberapa pihak yang terkait antara lain kepada perawat di RSUD Dr. M. Yunus Bengkulu, diharapkan dapat menerapkan terapi kognitif dalam melakukan intervensi keperawatan pada pasien gagal ginjal kronik yang menjalani terapi hemodialisa untuk mengurangi kecemasannya.

Bagi instansi pendidikan diharapkan mampu meningkatkan pendidikan tentang terapi kognitif dan menekankan kepada mahasiswa untuk dapat memberikan terapi kognitif dalam praktik di instansi pelayanan kesehatan dan saat berinteraksi dengan pasien yang mengalami kecemasan.

Selanjutnya bagi peneliti lain hendaknya dapat mengkaji faktor lain meliputi komunikasi therapeutik, pendidikan kesehatan, dan relaksasi yang dapat mempengaruhi kecemasan pasien hemodialisa. Penelitiannya dapat dilakukan dengan memperbanyak sampel yang diteliti sesuai dengan penghitungan rumus, menggunakan desain quasi eksperimen dengan kelompok pembanding, sehingga didapatkan hasil yang lebih maksimal.

New York : Wiley Inc. Diakses tanggal 23 September 2012

Brunner and Suddarth. 2001. Buku Ajar Keperawatan Medikal Bedah Edisi 8 Volume 2. Jakarta:EGC

Davison and Kring. 2004. Abnormal Psychology 10th Edition. New York : Wiley Inc. Diakses tanggal 23 September 2012

Ellis et all. 1999. Komunikasi Interpersonal Dalam Keperawatan. Jakarta : EGC

Eldido. 2008. Cognitive therapy. Diakses tanggal 24 September 2012. www.kerriemearns.com

Holmes, D. 2005. Cognitive Therapy for Depression and Anxiety. Diakses tanggal 24 September 2012

Kasjono. 2009. Teknik Sampling Untuk Penelitian Kesehatan Ed 1.Yogyakarta :Graha Ilmu 
Majnun, D. 2009. Terapi Modalitas dalam Keperawatan Jiwa. Diakses tanggal 07 November 2012. http://dahliarsj13.blogspot.com

Nasir, A \& Muhith, A. 2011. Dasar-dasar Keperawatan Jiwa Pengantar dan Teori. Jakarta : Salemba Medika

Suliswati. 2005. Konsep Dasar Keperawatan Jiwa. Jakarta : EGC

Wahyuningsih dkk. 2011. Pengaruh Terapi Kognitif Terhadap Kecemasan Pada Pasien
Kanker Serviks Di RS Margono Soekarjo Purwokerto dalam Jurnal Riset Kesehatan. Semarang : UP2M Poltekkes Kemenkes Semarang

Wayan, D. 2012. Hubungan Lama dan Frekuensi Menjalani Hemodialisa dengan Tingkat Kecemasan Terkait Alat Dialisa. Diakses tanggal $26 \quad$ September 2012. www.darsananursejiwa.blogspot.com

Yosep, I. 2009. Keperawatan Jiwa. Bandung :Refika Aditama 